\title{
The Impact on Unemployment of Social Security Contributions: the Empiricial Analysis in
} Turkey

\author{
Filiz Giray \\ Uludag University \\ Mehmet Çınar \\ Uludag University
}

\begin{abstract}
Social security contributions are important public incomes after taxes in OECD countries. Beside, social security contributions as a mean of the finance of social security system is a determiner on the main macroeconomic factors such as savings, employment, the cost of employment, the level of shadow economy, economic growth, competitiveness and income inequality. Employment has been important policy goals in Turkey like many OECD countries during recent decades. High unemployment rate is a serious problem for countries. Effecting negatively labor market, high burden of social security contributions causes low level of employment. The aim of this study is to find the relationship between social security contributions and unemployment for Turkey. Therefore, we can evaluate whether reducing social security contributions is a way reducing of unemployment or not. We use time series data during period 1965-2015. The research methodology is based on an analysis of indicators as unemployment rate, social security contributions as percentage of GDPs, the percentage of total tax revenues. Unit root test is non-stationary for social security contributions. On the other hand, unemployment is stationary for related period. The long run relationship between variables was tested by ARDL bound test approach. Based on the sample results, there is a long run cointegration between social security contributions and unemployment rate (both as percentage of GDP and percentage of taxation).
\end{abstract}

Keywords: Social security contributions, unemployment, employment, labor market.

\section{Introduction}

Social security services make an important contribution to the welfare of individuals. Many countries finance social security system which provides social services such as pensions and disability insurance, health insurance, unemployment benefits with social security contributions. Social security contributions are shared partly by employee, employer and partly selfemployed persons. Therefore, the burden of social security contribution is shared between employer and employee. Contributions depend on employees' earnings. Contribution rates are generally flat rate. Social security contributions can't be seen not only a tool of finance but also they are elements which impact on the main macroeconomic factors such as employment, the cost of employment, savings, shadow economy, economic growth and competitiveness. The subject of this study is related to the effects of these contributions on unemployment. Unemployment is a crucial problem in many countries. Turkey has high unemployment rate issue, too. In recent years, it has been though that growing burden of social security contributions has been made responsible for high unemployment rate. Knowing the extent of participation of high social security contributions in the unemployment, we will be given an opportunity for struggle against unemployment. This paper contributes to the empirical literature concerning the relationship between social security contributions and unemployment.

The paper is organized as follows: Section 2 explains the effects of social security contributions on demand and supply of labor. In the third section, previous literature is given. In following section, the relationship between social security contributions and unemployment as sample countries Turkey. Section 4 describes the data and the identification to estimate model. The last section concludes with a discussion of the implications of empirical results.

\section{The Effects of Social Security Contributions on Demand and Supply of Labor}


The equilibrium of the labor market requires that the marginal cost of work is equal to its marginal product (Cuesta and Olivera, 2014:1121). Social security contributions can shape registered employment in a country. High social security contributions paid by employers and employees can negatively effect on demand and supply of labor. Since high social security contributions increase the cost of employment for employers, employers reduce their demand of labor. The supply of labor is declined by employees. As result, unemployment level will be increased. Shadow economy begins to spread in all economy (Arandarenko and Vukojevic, 2008; Schneider, 2012; Stankevicius and Vasiliauskaité, 2014; Antón, 2014; Gankova - Ivanova, 2015; Binay, 2015). Second is illegal. Employers and employees differ to react to social security contributions. Social security contributions are seen like tax by employers. The reaction of employers depends on the incidence of social security burden. While employees pay these contributions, they establish a link between social security contributions and future benefits (Summers, 1989; Iturbe-Ormaetxe, 2015:741; Gustman and Steinmeier, 2005). Liebman, Luttmer and Seif (2009) investigated this link from point view of marginal Social Security benefits that include retirement age, hours, and labor earnings on labor supply. According to their empirical findings, individuals are incentive to retire that effective marginal social security contributions are high. Generally, social security contributions paid by employees can lead to a decline in their disposable income and in purchasing power in long run. Summary, the labor market response to high social security contributions can be negative. Therefore, a reduction the high social security contribution rates is accepted both in the policy arena and in the economics profession (Steiner, 1996:2). Governments are conducted to decrease social security contributions to promote labor formality and thus provide a larger employment of the population (Antón, 2014:1). When the effects of social security contributions are analyzed, some factors must be taken into account: the elasticity of labor demand and supply, the worker's valuation of the social security benefits, the presence of a binding minimum wage; and the bargaining power of workers in the labor market (Antón, 2014:2).

\section{Previous Literature}

In literature, the empirical studies of the effects of social security contributions on employment are most related to two streams. The first follows:

Natzmer (1987) suggested that social security contributions have affected negative on economic activities. Dewatripont et al. (1991) reached the result that a cut of social security contributions on unemployment level depends on type of tax. Financing with higher value added tax rate increases in question affect. Steiner (1996) investigated a reduction of the social security contribution rates are financed by increasing indirect taxes on employment for Germany. The result is a positive employment effect of reducing social security contribution rates in short-run, but modest effects remain due to higher wages in long-run. Daveri et al. (2000) found that labor taxes have a significant negative impact of on employment for EU countries. Buscher et al. (2001) analyzed employment effects of the cut in the contribution rate for a number of countries by using macroeconomic models. In study, it is claimed that a cut of social security contributions rate is financed by indirect taxes, in order not to let budget deficit. Bailey (2001) presented some strategies which are changes in the structure of social security, attitudinal changes by employers, employees and government, administrative changes, and solving macroeconomic problems (unemployment, inflation) to reduce contribution evasion in his study. Adjemian et al (2008) analyzed that the long run unemployment can be affected by the frictions in the labor market. Kunze and Schuppert (2010) suggested if cutting social security contributions rate is compensated by increase of capital income taxes, unemployment will be reduced. Antón (2014) investigated the effects of significant decrease in social security contributions in Colombia on labor markets. Accoring to finding, formal employment was increased between 3.4 and 3.7 percent. Binay (2015) analyzed the relationship between total social security contributions and the rate of social security contribution from point view of Laffer curve for Turkey during 2008-2012. He found that Laffer curve was validated in a statistically significant.

There are a few evidences for second stream. Gruber (1994) did not find any evidence the effect of mandated benefits on employment in the U.S. According to Cruces et al. (2010), any change in social security contributions and other labor taxes does not effect on employment in Argentina.

\section{The Relationship between the Social Security Contributions and Unemployment in Turkey}

Employment rate by age group indicates difference cross-country. Turkey had the lowest ratio of $33 \%$ in 2016 for aged 5564 , whereas Iceland had a ratio of $83.7 \%$, the highest in the OECD in 2016 (OECD date base). This indicator shows us unemployment issue for Turkey. On the other word, Turkey is under pressure from high unemployment rate. As seen Table 1 , Turkey unemployment rate has hit across countries. Turkey had the $4^{\text {th }}$ highest unemployment rate the 36 OECD member 
countries in 2016. Unemployment comes from high cost of labor. Despite of many reasons, social security contributions paid by employers is one of the main causes of high cost of labor.

Table 1. Unemployment rate in some OECD Countries in 2016

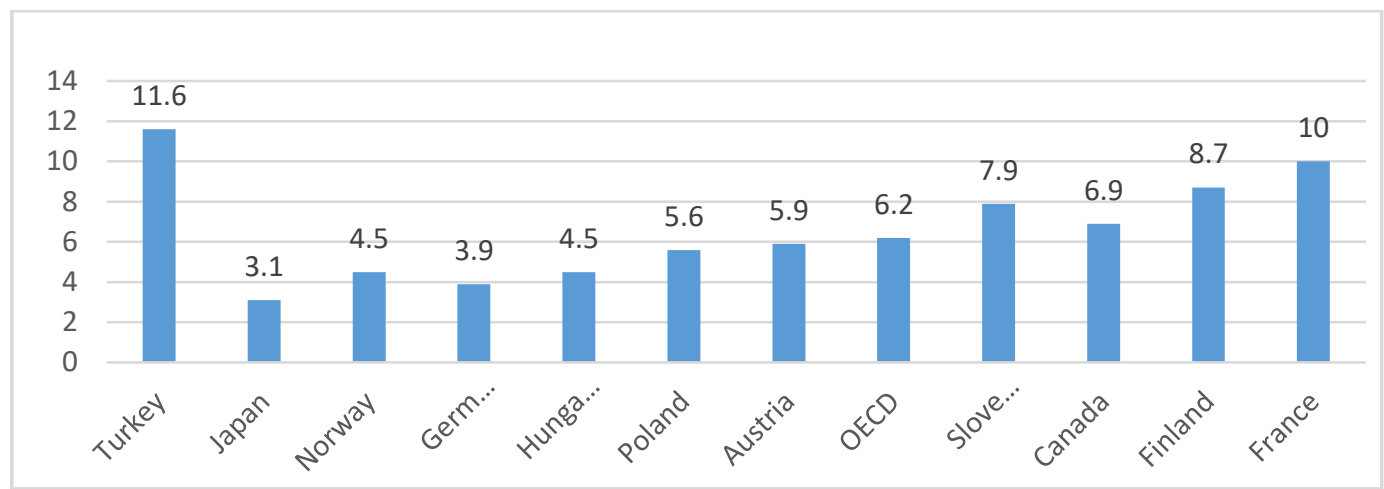

\section{Source: OECD Date Base.}

Turkish social security services were presented by three different administrations before the social security reform in the 2000s. Then, three administrations were consolidated as one government authority which is called the Social Security Administration. Social security contributions rate is an important issue because of widespread unemployment in Turkey. It can be observe a dramatic change after 2000's. Figure 1 indicates both unemployment rate and social security contributions as percentage of GDP occupied the highest level in 2009. Unemployment rate rose from \% 8 in 1990 to $\% 9.6$ in 2015. As similarly, the share of social security contributions in GDP raised 2.928 in 1990 to 8.207 in 2015.

Based on these indicators, it can be said that high social security contributions causes unemployment in Turkey.

Figure 1 Unemployment Rate and Social Security Contributions as percentage of GDP in Turkey

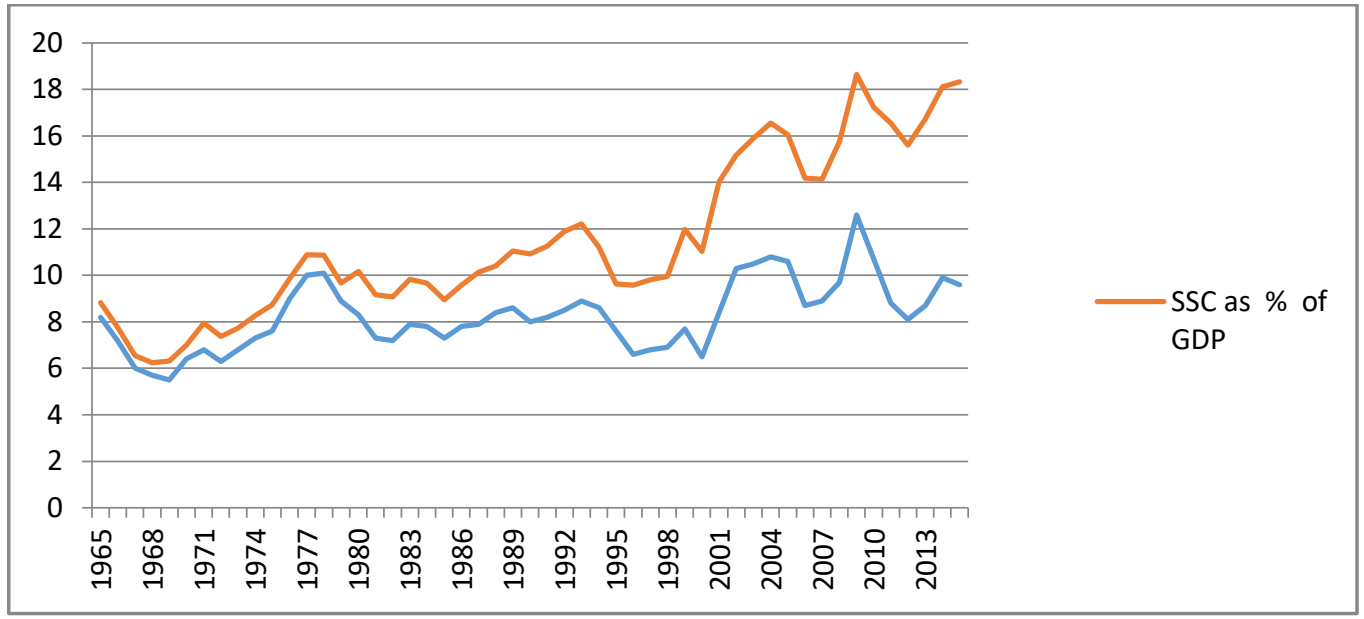

\section{Data and Methodology}


Data including social security contributions (SSC) and unemployment rate $\left(\mathrm{UNEMP}_{t}\right)$ series were gathered from the OCED and TUIK database for period 1965-2015. Social security contributions (SSC) were measured as the percentage of both gross domestic product $\left(\mathrm{SSC}_{-} \mathrm{GDP}_{\mathrm{t}}\right)$ and tax revenues $\left(\mathrm{SSC}_{-} \mathrm{TXT}_{\mathrm{t}}\right)$.

As methodology, this research steps are as follows: Time series unit root tests were performed: Augmented Dickey Fuller, Phillips-Perron test, and KPSS tests.

Time series cointegration tests were performed,

Long-run and short-run models were performed,

and at last most proper model was selected.

First step is determines stationary levels of relevant variables. In our study, it is used Dickey-Fuller (DF) (1979) test which is one of unit root test.

$\Delta y_{t}=\mu+\beta t+\delta y_{t-1}+\sum_{j=1}^{k} \alpha_{j} \Delta y_{t-j}+\varepsilon_{t}$

If $\delta=0$, the $\mathrm{y}_{\mathrm{t}}$ series is non-stationary or has a unit root. In equation (1), lagged values of depended variables are added into the model for white noise of error term. For this reason, this test is called Augmented Dickey Fuller (ADF) test. The optimal $k$ is determined by Akaike info Criteria (AIC) and Schwarz info Criteria (SIC) (Ng and Perron, 1995). Dickey and Fuller (1979) show that under the null hypothesis of a unit root, test statistic of $\delta$ does not follow the conventional Student's t-distribution and they derive asymptotic results and simulate tau critical values for various test and sample sizes.

The one of the most used unit root test is Phillips-Perron (PP) test. Phillips and Perron (1988) propose an alternative (nonparametric) method of controlling for serial correlation when testing for a unit root. The PP method estimates the non-augmented DF test equation (1). Therefore, Phillips and Perron (1988) add a correction term on Dickey-Fuller (1979) equation. That is

CF

$$
\mathrm{Z}_{\alpha}=\mathrm{T}\left(\hat{\phi}_{1}-1\right)-\mathrm{CF}
$$

(2)

Where, $\mathrm{CF}$ is correction term and calculates as follows:

$$
\mathrm{CF}=\frac{0.5\left(\mathrm{~s}_{\mathrm{T} \ell}^{2}-\mathrm{s}_{\varepsilon}^{2}\right)}{\sum_{\mathrm{t}=2}^{\mathrm{T}}\left(\mathrm{y}_{\mathrm{t}-1}-\overline{\mathrm{y}}_{-1}\right)^{2} / \mathrm{T}^{2}}
$$

Where, $s_{\varepsilon}^{2}$ is long-run variance. Lastly, PP (1988) test is calculated as follows: 


$$
\mathrm{Z}_{\tau}=\left(\sum_{\mathrm{t}=2}^{\mathrm{T}} \mathrm{y}_{\mathrm{t}-1}^{2}\right)^{1 / 2} \frac{\left(\hat{\phi}_{1}-1\right)}{\mathrm{s}_{\mathrm{T} \ell}}-(1 / 2) \frac{\left(\mathrm{s}_{\mathrm{T} \ell}^{2}-\mathrm{s}_{\varepsilon}^{2}\right)}{\left[\mathrm{s}_{\mathrm{T} \ell}^{2}\left(\mathrm{~T}^{-2} \sum_{\mathrm{t}=2}^{\mathrm{T}} \mathrm{y}_{\mathrm{t}-1}^{2}\right)^{1 / 2}\right]}
$$

(4)

Andrews (1991) shows optimal $\ell$ is $\ell=o\left(T^{1 / 3}\right)$ for lags parameter consistency. Schwert (1989) revealed, if size distortion is corrected in PP test, PP test is the more powerful than DK test.

While the null hypothesis is non-stationary of the series in ADF (1979) and PP (1988) unit root tests, alternative hypothesis series is the stationary of the time series. However, in new unit root test which has been developed by Kwiatkowski, Phillips, Schmidt and Shin (KPSS) (1992), the null hypothesis series is stationary. Alternative hypothesis series is non-stationary. That is, hypothesis in KPSS test is different from ASF and PP Tests. In framework above explained, it can be said that KPSS (1992) test is the more powerful than previous unit root tests.

In KPSS (1992) test, firstly deterministic components of series are removed. KPSS test model as follows:

$$
y_{t}=\beta t+w_{t}+\varepsilon_{t}
$$

(5)

$$
\mathrm{w}_{\mathrm{t}}=\mathrm{w}_{\mathrm{t}-1}+\mathrm{u}_{\mathrm{t}}
$$

Where, $\mathrm{w}_{\mathrm{t}}$ is random walk process, $\mathrm{t}$ is deterministic trend, $\varepsilon_{\mathrm{t}}$ is stationary errors and $\mathrm{u}_{\mathrm{t}}$ is $\operatorname{iid}\left(0, \sigma_{\varepsilon}^{2}\right)$. KPSS LM test statistics calculated as follows:

$$
\mathrm{LM}=\sum_{\mathrm{t}=1}^{\mathrm{T}} \mathrm{S}_{\mathrm{t}}^{2} / \mathrm{s}^{2}(\ell)
$$

Where, $\mathrm{s}^{2}(\ell)=\mathrm{T}^{-1} \sum_{\mathrm{t}=1}^{\mathrm{T}} \mathrm{e}_{\mathrm{t}}^{2}+2 \mathrm{~T}^{-1} \sum_{\mathrm{s}=1}^{\ell} \mathrm{w}(\mathrm{s}, \ell) \sum_{\mathrm{t}=\mathrm{s}+1}^{\mathrm{T}} \mathrm{e}_{\mathrm{t}} \mathrm{e}_{\mathrm{t}-\mathrm{s}}$ and square root number of observation ( $\left.\ell=\circ\left(T^{1 / 2}\right)\right)$ is used for consistent estimation of $S^{2}(\ell)$.

After determined stationary of the series, it can be used Autoregressive Distributed Lag (ARDL) model for testing long run relationship of the variables. An ARDL is a least squares regression containing lags of the dependent and explanatory variables. If we found mixed stationary levels of series, Johansen (1988) cointegration test cannot be used for determining of long run relationships of the variables. In this case ARDL model is used, which is developed Pesaran at al. (2001). The main advantage of ARDL model can be used in mixed stationary levels of series. The ARDL bound co-integration test model can be shown as follows:

$$
\Delta \mathrm{UNEMP}_{\mathrm{t}}=\alpha+\sum_{\mathrm{j}=1}^{\mathrm{m}} \beta_{1 \mathrm{i}} \Delta \mathrm{UNEMP}_{\mathrm{t}-\mathrm{j}}+\sum_{\mathrm{j}=0}^{\mathrm{n}} \beta_{2 \mathrm{i}} \Delta \mathrm{SSC}_{\mathrm{t}-\mathrm{j}}+\delta_{1} \mathrm{UNEMP}_{\mathrm{t}-1}+\delta_{2} \mathrm{SSC}_{\mathrm{t}-1}+\varepsilon_{\mathrm{t}}
$$


Where $\varepsilon_{t} \sim \operatorname{ID}\left(0, \sigma_{\varepsilon}^{2}\right)$ is white noise (WN) process. After estimating Equation (8), it is necessary to perform the ARDL boundary test to determine whether there is a long-term relationship between the variables. The boundary test is carried out under the following hypotheses:

$$
\begin{aligned}
& \mathrm{H}_{0}: \delta_{1}=\delta_{2}=0 \\
& \mathrm{H}_{1}: \delta_{1} \neq \delta_{2} \neq 0
\end{aligned}
$$

(9)

If the null hypothesis is rejected, it is reached that there is a long-term relationship between the variables. If the null hypothesis is non-rejected, there is no long-term relationship between the variables. When there is cointegration between the variables, long term and short-term relationships can be estimated.

$$
\mathrm{UNEMP}_{\mathrm{t}}=\alpha_{0}+\sum_{\mathrm{j}=1}^{\mathrm{m}} \alpha_{1 \mathrm{j}} \mathrm{UNEMP}_{\mathrm{t}-\mathrm{j}}+\sum_{\mathrm{j}=0}^{\mathrm{n}} \alpha_{2 \mathrm{j}} \mathrm{SSC}_{\mathrm{t}-\mathrm{j}}+\varepsilon_{\mathrm{t}}
$$

The model is known as ARDL $(m, n)$ model. Lag lengths $(m, n)$ are determined using information criteria such as AIC, SIC, HQ. After the model is estimated, if the model is diagnostically tested and is suitable, the Error Correction Model (ECM) is estimated as follows:

$$
\Delta \mathrm{UNEMP}_{\mathrm{t}}=\alpha_{0}+\sum_{\mathrm{j}=1}^{\mathrm{m}} \gamma_{1 \mathrm{j}} \Delta \mathrm{UNEMP}_{\mathrm{t}-\mathrm{j}}+\sum_{\mathrm{j}=0}^{\mathrm{n}} \gamma_{2 \mathrm{j}} \Delta \mathrm{SSC}_{\mathrm{t}-\mathrm{j}}+\gamma_{3} \mathrm{ECT}_{\mathrm{t}-1}+\varepsilon_{\mathrm{t}}
$$

Where $\gamma_{3}$ is the parameter of Error Correction Term $\left(\mathrm{ECT}_{\mathrm{t}-1}\right)$. It is expected that this parameter will be estimated

$$
\text { between }-1<\gamma_{3}<0 \text { and statistically significant. }
$$

\section{Empirical Results}

The first part of this result is to investigate the stationary properties of the variables. The first step in unit root tests is to determine the appropriate model structure and the number of lag lengths for each series. For this purpose, we have carried out strategic tests with the intercept and trend model to none (no intercept and trend) model for each of the series. The more appropriate model for the $\mathrm{UNEMP}_{t}$ and $\mathrm{SSC}_{\mathrm{t}}$ in text series is intercept and trend model. But for $\mathrm{SSC}_{\mathrm{t}}$ as percentage of GDP, appropriate model is none (no intercept and no trend) model. Also, we have found the number of lag lengths by using the Breusch-Godfrey LM test statistics in addition to information criteria such as AIC, SIC, HQ in the models. Table 2 shows the results of the three unit root tests.

Table 2 Unit Root Tests Results

\begin{tabular}{llll}
\hline VARIABLES & ADF & PP & KPSS \\
\hline UNEMP $_{\mathrm{t}}$ & $-4.1493^{\mathrm{b}}$ & $-3.1998^{\mathrm{c}}$ & 0.0619 \\
\hline SSC_GDP $_{\mathrm{t}}$ & 4.4508 & 3.1305 & - \\
\hline SSC_TXT $_{\mathrm{t}}$ & -2.5472 & $-3.4904^{\mathrm{c}}$ & 0.0651 \\
\hline
\end{tabular}

Note: a significant at $1 \%,{ }^{b}$ significant at $5 \%,{ }^{c}$ significant at $10 \%$.

According to Table 2, UNEMP $_{t}$ series is stationary for three unit root tests (at least $10 \%$ ), while SSC_GDP $_{t}$ is stationary. The appropriate model is none model for $S_{S C} G_{2} P_{t}$ variables, therefore we cannot applied KPSS unit root test. But there are found mixed results at SSC_TXT $\mathrm{T}_{\mathrm{t}}$ variables. That is, ADF test shows that the series 
is non-stationary. The series is stationary from point view of KPSS and PP $(10 \%)$ tests. Because of the different degrees of integration of the variables, it would be more appropriate to use the ARDL approach to investigate the existence of a long-run relationship between these variables. The first step of the ARDL approach is to determine the appropriate lag lengths for each of the variables. For this purpose, again, AIC, SIC, HQ and LM tests can be used. In the study, the maximum lag lengths were taken for 4 periods for both endogenous and exogenous variables. Accordingly, the lowest AIC, SIC and $H Q$ values were obtained for the $\operatorname{ARDL}(2,0)$.

Firstly, for the ARDL test to be valid, the bound test must be performed. In Table 3, Pesaran et al. (2001) bound test and diagnostic test results are shown.

Table 3 ARDL Bound Test Results

\begin{tabular}{|c|c|c|c|c|}
\hline Tested Models & \multicolumn{2}{|c|}{ TEROR = f(UNEMP,SSC_GDP) } & \multicolumn{2}{|c|}{ TEROR $=\mathbf{f}($ UNEMP, SSC_TXT $)$} \\
\hline F-statistics & $5.5874^{a}$ & & \multicolumn{2}{|l|}{$5.5789^{b}$} \\
\hline Optimum Lag Length & {$[2,0]$} & & \multicolumn{2}{|l|}{$[2,0]$} \\
\hline \multirow[b]{2}{*}{ Significance Levels } & \multicolumn{4}{|c|}{ Bounds Critical Values } \\
\hline & Upper Bound & Upper Bound & Upper Bound & Upper Bound \\
\hline $1 \%$ & 4.94 & 5.58 & 4.94 & 5.58 \\
\hline $5 \%$ & 3.62 & 4.16 & 3.62 & 4.16 \\
\hline $10 \%$ & 3.02 & 3.51 & 3.02 & 3.51 \\
\hline \multicolumn{5}{|c|}{ Diagnostic Test Results } \\
\hline $\mathbf{R}^{2}$ & 0.7072 & & 0.7071 & \\
\hline$\overline{\mathbf{R}}^{2}$ & 0.6877 & & 0.6876 & \\
\hline F-Statistics & 36.2349 a & & $36.2141^{a}$ & \\
\hline Breusch-Godfrey LM & 0.1484 & & 0.0431 & \\
\hline ARCH LM & 1.5790 & & 1.6460 & \\
\hline
\end{tabular}

Note: a significant at $1 \%$. ${ }^{b}$ significant at $5 \%$.

The null hypothesis will be rejected because the F-statistic value (5.5874) calculated for the bound test in Table 3 is greater than the upper critical value of 5.58 at the $1 \%$ significance level. That is, according to the ARDL bound test, there is co-integration relationship between the variables. Then there is a long-run relationship between $\mathrm{UNEMP}_{t}$ and SSC_GDP $t$ variables. Also, similar results are found between $\mathrm{UNEMP}_{t}$ and $\mathrm{SSC}_{-} \mathrm{TXT}_{\mathrm{t}}$ variables.

Secondly, Table 3 indicates diagnostic test results for co-integration. When Table 3 is examined, the model is generally meaningful; there are no autocorrelation problems and no heteroscedasticity problem for both models. Thus, in order to demonstrate the long- and short-term relationships between variables, the long-run combined model and the error correction model results are given in Table 4.

Table 4 Long-Run and Error Correction Models Estimation Results

\begin{tabular}{|c|c|c|c|c|c|c|}
\hline & Panel A: Lon & odel Results & & & & \\
\hline Variables & Coefficients & Std. Errors & t-Statistics & Coefficients & Std. Errors & t-Statistics \\
\hline $\mathrm{SSC}_{-} \mathrm{GDP}_{\mathrm{t}}$ & $0.3553^{a}$ & 0.1178 & 3.0144 & & & \\
\hline $\mathrm{SSC}_{-} \mathrm{TXT}_{\mathrm{t}}$ & & & & $0.1220^{a}$ & 0.0406 & 2.9998 \\
\hline CONS. & $7.1310^{a}$ & 0.4791 & 14.8861 & 6.3099 a & 0.7216 & 8.7440 \\
\hline
\end{tabular}




\begin{tabular}{|l|lll|lll|}
\hline & \multicolumn{9}{|c|}{} & & \\
\hline Variables & Coefficients & Std. Errors & t-Statistics & Coefficients & Std. Errors & t-Statistics \\
\hline ECT $_{\mathrm{t}-1}$ & $-0.4315^{\mathrm{a}}$ & 0.1058 & -4.0805 & $-0.4277^{\text {a }}$ & 0.1066 & -4.0119 \\
\hline$\Delta \mathrm{UNEMP}_{\mathrm{t}-1}$ & $0.3726^{\mathrm{a}}$ & 0.1322 & 2.8186 & $0.3675^{\mathrm{a}}$ & 0.1343 & 2.7368 \\
\hline$\Delta \mathrm{SSC}_{-} \mathrm{GDP}_{\mathrm{t}-1}$ & 0.0952 & 0.2505 & 0.3801 & & & \\
\hline$\Delta \mathrm{SSC}_{-} \mathrm{TXT}_{\mathrm{t}-1}$ & & & & -0.0124 & 0.0553 & -0.2250 \\
\hline
\end{tabular}

Note: a significant at $1 \%$, ${ }^{\text {b }}$ significant at $5 \%,{ }^{c}$ significant at $10 \%$.

Firstly, Panel A shows the long-run relationship results in Table 4. According to these results, it is seen that there is a positive and statistically significant relationship between unemployment rate and social security contribution (both a percentage of GDP and a percentage of tax revenues) in the long run. Based on this result, if social security contributions are increased $1 \%$, unemployment rate is increased $0.35 \%$ level. In other words, social security contributions have an impact on the rising of unemployment rate in the long run. Similar results were obtained for the share of social security contributions in tax variable. This result is compatible with relevant literature. Long run mean of unemployment rate is $7.13 \%$ as a percentage of GDP (or $6.31 \%$ as a percentage of tax revenues) and these coefficients are statistically significant at $1 \%$.

In Table 4 Panel B shows both short-term and error correction results. First, the error correction term $\left(\mathbf{E C T}_{\mathbf{t}-\mathbf{1}}\right)$ is negative and statistically significant as expected for two models. That is, the imbalances that occur in the short term are removed from the long term (43.15\% and $42.77 \%)$ and the series are again close to the long term equilibrium values. Therefore, the error correction model is valid for two models.

Secondly, when the parameters affecting the short term are examined, the following conclusions are reached. In the short term, it was found that there is a positive but statistically insignificant relationship between unemployment rate and social security contribution of both models. On the other word, in the short run the social security contribution has not been effective on unemployment rate for both models.

\section{Conclusion}

Social security contributions are a tool of social services such as pensions and disability insurance, health insurance, unemployment benefits. From point of view of an economic perspective, they have effects on economic variables which the unemployment is one. Unemployment is crucial problem for countries. For this reason, many countries combat with this issue. Social security contributions for employers are a cost of labor. The aim of this study is to find the relationship between social security contributions and unemployment for Turkey. Therefore, we evaluate whether reducing social security contributions are a way reducing of unemployment or not. We use time series data. The research methodology is based on an analysis of indicators as unemployment, social security contributions as percentage of GDPs, the percentage of total tax revenues. Applied ARDL co-integration test shows that there is long-run relationship between unemployment rate and social security contributions in both cases. But in short run, we cannot found significant relationship between the variables. Therefore these results indicate that social security contributions only affect to unemployment in long-run in Turkey. According to this empirical evidence, an efficient management of social security contributions rate can reduce unemployment, which are required a long run progress. The social security contributions are seen as a tool in controlling unemployment. These finding are supported by previous literature on this topic. The loss of contributions can be compensated by various income sources like indirect taxes or subsidies. Additionally, a reduction of social security contributions rate will be raised economic growth. These empirical results should be a priority for future research.

\section{References}

[1] Adjemian, S., F. Langot, C. A. Q, Rojas, Growth (2008). Growth Unemployment and Tax/Benefit System in European Countries, MPRA Paper No. 7909.

[2] Antón, A. (2014). 'The Effect of Payroll Taxes on Employment and Wages under High Labor Informality', Journal of Labor \& Development, 3(20), 1-23. 
[3] Arandarenko, M. \& Vukojevic, V. (2008). Labor Costs and Labor Taxes in the Western Balkans. In C.Bredenkamp, M.Gragnolati and V.Ramljak (Eds.), Enhancing Efficiency and Equity: Challenges and Reform Opportunities Facing Health and Pension Systems in the Western Balkans, Washington, DC: The World Bank.

[4] Bailey (2001).'Strategies to Reduce Contribution Evasion in Social Security Financing', World Development, 29(2), 385-393.

[5] Binay, M. (2015). 'The Laffer Effect at Turkish Social Security Administration's Premium Revenue', Procedia Economics and Finance, 26, 592 - 597.

[6] Binay, M. (2015). 'Optimal Informal Employment Ratio for Turkish Economy', Procedia Economics and Finance, 26, 598-602.

[7] Buscher, H. S., H. Buslei, K. Göggelmann, H. Koschel, T.F.N. Schmidt, V. Steiner, P. Winker (2001). 'Empirical Macro Models under Test. A Comparative Simulation Study of the Employment Effects of A Revenue Neutral Cut in Social Security Contributions', Economic Modelling, 18, 455-474.

[8] Cruces G, Galiani S, Kidyba S (2010). Payroll Taxes, Wages and Employment: Identification through Policy Changes', Labour Economics, 17, 743-749.

[9] Cuesta, J. and M. Olivera (2014).'Science Direct the Impact of Social Security Reform on the Labormarket: The Case of Colombia', Journal of Policy Modeling, 36, 1118-1134.

[10] Dickey, A. David and Fuller A. Wayne (1979). 'Distribution of the Estimators for Autoregressive Time Series With A Unit Root', Journal of American Statistical Association, 74, 427-431.

[11] Daveri F, Tabellini G, Bentolila S, Huizinga H (2000).'Unemployment, Growth and Taxation in Industrial Countries', Econ Policy, 15(30), 47-104.

[12] Gankova - Ivanova, T. (2015) 'Interactions between the Shadow Economy and the Social Security System', 1 st International Conference on Business Management, València.

[13] Gruber J (1994).'The Incidence of Mandated Maternity Benefits', American Economic Review, 84, 622-641.

[14] Gustman, A. L., T. L. Steinmeier, (2005). 'Imperfect Knowledge of Social Security and Pensions', Industrial Relations, 44 (2), 373-397.

[15] Johansen, S. (1988). 'Statistical Analysis of Co-Integration Vectors', Journal of Economic Dynamics and Control, 12(2/3), 231-254.

[16] Kwiatkowski, D., P.C. B. Phillips, P. Schmidt, and Y. Shin. (1992), "Testing the Null Hypothesis of Stationarity against the Alternative of A Unit Root", Journal of Econometrics, 54, 159-178.

[17] Kunze, L. and C. Schuppert (2010). 'Financing social security by taxing capital income: A bad idea', FinanzArchiv/Public Finance Analysis, 66(3), 243-262.

[18] Liebman, J. B., E.F.P. Luttmer and D. G. Seif (2009).'Labor Supply Responses to Marginal Social Security Benefits: Evidence from Discontinuities', Journal of Public Economics, 93, 1208-1223.

[19] Natzmer, W. V. (1987). "Social Security Contributions, Economic Activity and Distribution", Empec, 12, 29-49.

[20] Ng, S. and P. Perron. 'Unit Root Tests in ARMA Models with Data-Dependence Methods for the Selection of the Truncation Lag', Journal of the American Statistical Association, 90(429), 1995, 268-281.

[21] Iturbe-Ormaetxe, I. (2015). 'Salience of Social Security Contributions and Employment', Interntaional Tax Public Finance, 22, 741-759.

[22] OECD, Date base.

[23] Pesaran, M. H., Y. Shin, and R. J. Smith. (2001). 'Bounds Testing Approaches to The Analysis of Level Relationships', Journal of Applied Econometrics, 16, 289-326.

[24] Phillips, C. B. P. and P. Perron (1988). 'Testing For A Unit Root in Time Series Regression', Biomètrika, 75(2), 336-346.

[25] Schwert, G. W. (1989). 'Tests for Unit Roots: A Monte Carlo Investigation', Journal of Business \& Economic Statistics, 7(2), 147-159.

[26] Schneider, F. (2012).'The Shadow Economy and Work in the Shadow: What Do We (Not) Know?, Discussion Paper, No. 6423.

[27] Stankevicius, E. and A. Vasiliauskaité (2014) 'Tax Burden Level Leverage on Size of the Shadow Economy, Cases of EU Countries 2003-2013', Procedia - Social and Behavioral Sciences, 156,548 - 552.

[28] Steiner, V. (1996). 'Employment and Wage Effects of Social Security Financing - An Empirical Analysis of the West German Experience and some Policy Simulations', Discussion Paper, No. 96-14. 
[29] Summers, L. (1989). 'Some Simple Economics of Mandated Benefits', American Economic Review, 79(2), 177-183. 